\title{
SOFT SKILL DEVELOPMENT STRENGTHENING PROGRAM BUSINESS ENTREPRENEURSHIP
}

\author{
${ }^{1}$ Nugroho Juli Setiadi, ${ }^{2}$ Agung Hari Sasongko, ${ }^{3}$ Jajat Sudrajat ${ }^{4}$ Meiryani \\ ${ }^{1}$ BINUS Business School Undergraduate Program, Management Department, Bina Nusantara \\ University, Jakarta, Indonesia 11480 \\ ${ }^{2}$ BINUS Entrepreneurship Center, Bina Nusantara University, Jakarta Indonesia 11480 \\ ${ }^{3}$ BINUS Entrepreneurship Center, Bina Nusantara University, Jakarta Indonesia 11480 \\ ${ }^{4}$ Accounting Department, Faculty of Economics and Communication, Bina Nusantara University, \\ Jakarta, Indonesia 11480 \\ nugroho.setiadi@binus.edu
}

Received: January $19^{\text {th }}, 2021 /$ Revised: February $18^{\text {th }} 2021 /$ Accepted: March $12^{\text {th }}, 2021$

\begin{abstract}
The program to strengthen the concept of genetic intelligence as a concept to improve student soft skills was chosen as one of the concepts and methods to be used for student entrepreneurial development using the experiential learning model. Experiential learning approach is a learning approach where knowledge is constructed through experience transformation. In the concept of genetic intelligence or familiar with the term STIFIn Concept, there are 5 parts of the brain, namely Sensing, Thinking, Intuiting, Feeling and Instinct. The brain turns out to have different parts and chemistry. The results of the STIFIn Concept analysis are knowing the dominance of a person's right or left brain, so that it can be the basis for choosing the right field of entrepreneurship, business partners and business mentors according to their genetic intelligence.
\end{abstract}

Keywords: genetic intelligence; Soft Skill; experiential learning; STIFIn Concept

\section{Introduction}

To support the mission of the Directorate of Research and Community Service (DRPM) in the program to produce new entrepreneurs from campus. One of the Bina Nusantara University programs is targeting graduates to work in global companies or become entrepreneurs (Entrepreneurship). To achieve this target, a work unit or center is formed with the name Binus Entrepreneurship Center (BEC), which is in charge of managing Entrepreneurship courses, where All students are required to take the Entrepreneurship I course in semester 3 and Entrepreneurship II in semester 5. In addition to studying formally in class, the Entrepreneurship course also requires students to take part in the Binus Festival (Bifes), activities in the form of competitions to make a Business Plan and an exhibition of products or services. student ideas that are discussed in groups in class.

The problem is that there are many students' business ideas that are not in accordance with their study program, they do not understand that the courses accepted in their study program can be developed in entrepreneurship subjects, according to the competence of students studying in their respective study programs. Based on data from the student affairs unit of BINUS; Student Creativity Development Center (SCDC), http://student.binus.ac.id/student-creativity-development-center-scdc/. The number of student groups that submitted PKM proposals in 2017 was 525 proposals, consisting of 425 proposals for "5 fields" and 100 proposals for "Writing". Based on the announcement on March 3, 2018, only 3 groups of "Research Fields" were funded by the Higher Education. In 2017, it is targeted that more than 1,500 proposals will be made by students, then evaluated into 900 proposals that will compete in the Binus Student Scientific Week (PIMBINUS) and 525 proposals will be prepared to be submitted to the 
Higher Education. In 2017, there were 170 incubation tenants (resident starter entrepreneurs) who were registered at the BINUS Incubator institute. Apart from the Binus Entrepreneurship Center (BEC) unit which manages the process of implementing the entrepreneurship curriculum, there is also the Binus Incubator Institute, specifically for students who are interested in entrepreneurship. They study entrepreneurship for one semester starting from 09.00 to 18.00 .

Bina Nusantara University has one of the missions "Providing a world-class teaching, learning and research experience that fosters excellence in scholarship, innovation and entrepreneurship". In view of this mission, BINUS has an obligation to continuously improve and maintain the quality, creativity and innovation of BINUS students. Innovation is one of the factors that determine the Global Competitiveness Index or the competitiveness of the Indonesian people compared to other countries in the World Economic Forum (weforum.org). One of the places that can improve quality and creativity and produce innovation based on knowledge for BINUS students is the Student-Entrepreneurship Creativity Program (PKM-K) and other PKM, where innovation is one of the values in BINUS students. The program to strengthen the concept of genetic intelligence as a concept to improve student soft skills was chosen as one of the concepts and methods to be used for student entrepreneurial development using the experiential learning model. Experiential learning approach is a learning approach where knowledge is constructed through experience transformation. In the concept of genetic intelligence or familiar with the term STIFIn Concept (Poniman \& Mangussara, 2012), there are 5 known parts of the brain, namely Sensing, Thinking, Intuiting, Feeling and Instinct. The brain turns out to have different parts and chemistry. The results of the STIFIn Concept analysis are knowing the dominance of a person's right or left brain, so that it can be the basis for choosing the right field of entrepreneurship, business partners and business mentors according to their genetic intelligence.

This activity starts with students either in groups or individually who are interested in developing their business ideas, after they have taken the Entrepreneurship course for 2 semesters (semester 3 and 5). We would recommend taking a Genetic Intelligence Workshop to generate innovative and creative ideas according to the subject's learning topic or object of interest to students according to their study program. After that, students attend 4 training stages to translate these ideas into a Business Plan. After the Business Plan is completed, the Entrepreneurship Development Program team will conduct an assessment. The criteria for students who take this program are prioritized for students who have participated in PKM-K and other PKM as well as students who are starting new businesses. The target audience is 20 students divided into groups and individuals.

In implementing the Entrepreneurship Development Program, training on entrepreneurship will be carried out, through the concept of genetic intelligence. The training was divided into 4 (four) meetings, the first meeting was the Introduction to the Concept of "Genetic Intelligence", the second meeting was enrichment on "Entrepreneurial Motivation", the third meeting was enrichment on "Busienss Plan" and the last meeting was enrichment on "Management Skills".

After this activity takes place students can have the insight and skills to start entrepreneurship or develop their existing business and it is hoped that they can actively participate in entrepreneurship competitions, such as the Indonesian Student Business Competition (KBMI), Independent Young Entrepreneur (WMM) and other competitions both in national and international levels

\section{Partner Profile Analysis}

In 2017, there were 170 incubation tenants (resident starter entrepreneurs) who were registered at the BINUS Incubator institute (Sasongko, 2017). Apart from the Binus Entrepreneurship Center (BEC) unit which manages the process of implementing the entrepreneurship curriculum, there is also the Binus Incubator Institute, specifically for students who are interested in entrepreneurship.

The scope of the Genetic Intelligence Strengthening Program, the participants are active students of the Bina Nusantara University Undergraduate (S1) program. The focus of the program is to improve entrepreneurial skills by making a Business Plan as an output of activities. 
BINUS Incubator is managed by 4 staff (Gunawan, 2017) with efficient management by providing the following services:

1. Room (Space.), Where the incubator provides a place to develop a business at an early stage.

2. Provision of Facilities (Shared), which means that the incubator provides office facilities that can be used together, for example receptionists, conference rooms, telephone systems, facsimiles, computers and networks, as well as work security systems.

3. Services, including management consulting and market issues, financial and legal aspects, trade information and technology.

4. Support, in this case the incubator helps access to research, professional networks, technology, international, and investment.

5. Skill Development, can be done through training in preparing business plans, management, and enhancing other human resources capabilities.

6. Access to finance (seed capital) can be done through financing programs for startups from various parties, including the government, corporate CSR or by helping small businesses access sources of funding or venture capital financial institutions.

7. Synergy (Synergy), is a tenant cooperation and network improvement with tertiary institutions, research institutes, associations, private businesses, professionals and the international community..

\section{Partner Problems}

Based on this background, the following problems can be identified:

a. The importance of BINUS students is to develop skills in making Business Plan and managing a business.

b. The need to facilitate BINUS students to be able to have competency standards in making Business Plans and managing businesses.

c. The importance of entrepreneurship training methods at BINUS in accordance with the potential of students' genetic intelligence

\section{Solution to Troubleshooting}

The solution of the Genetic Intelligence Strengthening Program for the development of this Soft Skill is

a. Improve the competence of BINUS students in the skills of making Business Plan.

b. Providing education to BINUS students about entrepreneurial insights using the concept of Genetic Intelligence to develop student potential in increasing business cooperation

c. Creating entrepreneurial training methods at BINUS according to the potential of students' genetic intelligence.

\section{Implementation Method}

The Implementation Method in the Entrepreneurship Development Program (PPK) begins by distributing questionnaires to students who are studying entrepreneurship courses. The questionnaire material includes the following:

Part 1: Determining qualities of entrepreneurial success;

a. Determination and persistence

b. Confidence

c. Friendly to everyone

d. Attention and passion

e. Creativity and abilities

f. Loves to take risks

g. Intelligence 
h. Honesty

i. Sensitivity

j. Commitment / willpower

k. Act according to a plan

1. Open to criticism

Figure 1 shows the result of descrptive analysis to explore students' perceived importance and the selfassessment of entrepreneurial qualities.

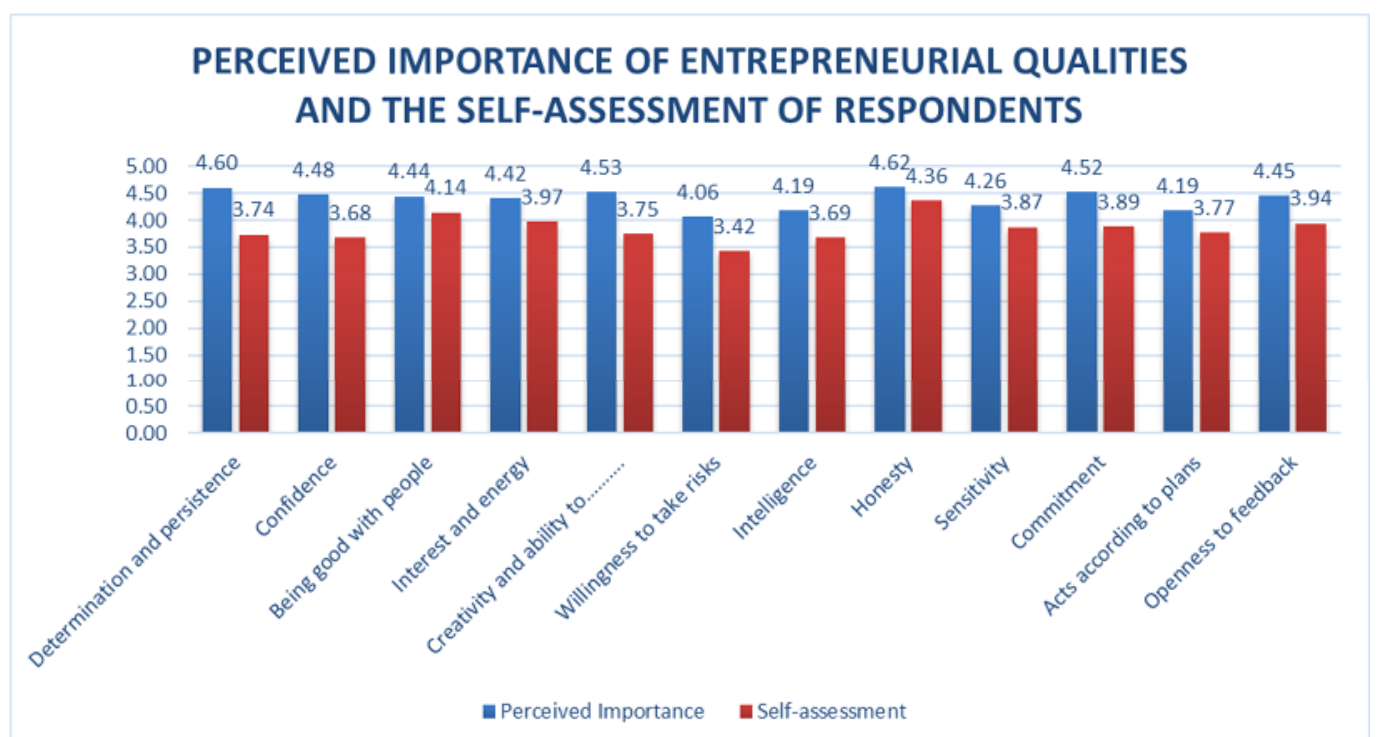

Figure1 Perceived importance of entrepreneurial qualities and the self-assessment of respondents

\section{Conclusion}

The number of respondents who filled out the questionnaire was 83 (eighty three) students, who filled in "Determination and Persistence" as a determinant of the quality of entrepreneurial success as much as $67 \%$, other criteria ranging from "Confidence" to the criteria "Open to Criticism" below 50\%, so that the conclusion:

1. The ability of students to generate creative and innovative ideas through the concept of Genetic Intelligence still needs to be improved to motivate and improve new entrepreneurs

2. Students' abilities in making Business Plans and participating in national and international competitions in 2020 still need to be improved, thereby increasing the network of business partners

3. The ability of students to generate creative and innovative ideas through the concept of Genetic Intelligence still needs to be improved through the incubator development pattern that is accommodated in incubation institutions.

4. The ability of students in making Business Plans and participating in national and international competitions in 2020 still needs to be improved through coaching with instructors who are accommodated in incubation institutions.

In order for the potential of students to become UMKM and the community in entrepreneurship according to their talents and interests and competencies according to their majors, students and lecturers should know the student's entrepreneurial soft skills, so that students can show teamwork skills such as collaboration, division of tasks in multidisciplinary teams to facilitate better performance. optimal. Students are given the concept of 9 components of the Business Model (BMC) Canvas, namely Customer Segment (CS), Channel (C), Customer Relationship (CS), Key Partners (KP), Key Activities (KA), Key Resources (KR), Cost structure ( CS) and Revenue Stream (RS)(Osterwalder \& Pigneur, 2010). Each component is related to each other according to business ideas made by students in groups consisting of several multidisciplinary groups. 


\section{References}

Darmanto, Susetyo and Wahyudi, Sugeng, 2020.. Developing Intention and Entrepreneurial Behavior Through the Mediating Role of Entrepreneurial Self Efficacy Maturity (An Empirical Study on University Students in Semarang, Indonesia) (February 13, 2014). Available at SSRN: https://ssrn.com/abstract=2395090 or http://dx.doi.org/10.2139/ssrn.2395090. Retrieved on July 01, 2020

Era Genetik, Yayasan Qurrotu A’yun, Bekasi, Cetakan kedua : Desember 2017, ISBN 978-60261342-0-2

Farid Poniman, Sang Penemu Konsep STIFIn, https://www.donita.co.id/farid-poniman-stifin/ Diakses tanggal 5 April 2018

Gunawan, Sasongko 2017, Laporan Akhir Hibah Penguatan kelembagaan Inkubator 2017

Indarti, Nurul et al. 2010. Underlying Factors of Entrepreneurial Intentions among Asian Students. The South East Asian Journal of Management, Volume IV, No.2. October 2010.

Indarti, Nurul; and Rostiani, Rokhima. 2008. Intensi Kewirausahaan Mahasiswa: Studi Perbandingan antara Indonesia, Jepang dan Norwegia. Jurnal Ekonomika dan Bisnis Indonesia, Vol. 23, No. 4, Oktober 2008. http://modul.repo.mercubuanayogya.ac.id/modul/files/openjournal/Journall/physicology/indarti-rostiani-jebi-2008.pdf. Retrieved on July 01, 2020.

Osterwalder, A., \& Pigneur, Y. (2010). Business model generation: a handbook for visionaries, game changers, and challengers. John Wiley \& Sons.

Panca Rona, Yayasan STIFIn,Bekasi, Farid Poniman, Cetakan kedua : Februari 2018

Sasongko H Agung, 2017 Proposal Program Penguatan Kelembagaan Inkubator Bisnis Teknologi.

Setiadi, N.J. et al. 2007b. The impact of personal characteristics and intrinsic motivation on creative behavior among Indonesian radio station managers. The South East Asian Journal of Management, 1(1), 105-119, $2007 b$.

Setiadi, Nugroho J; and Puspitasari, Monica. 2014. Empirical Study of Entrepreneurial Attitudes and Intentions among Indonesian Business Students. DLSL Journal of Management, Volume 1 Issue 1, January 2014. ISSN 2350-7802.

https://www.researchgate.net/profile/Nugroho_Setiadi/publication/260021511_Empirical_st udy_of_entrepreneurial_attitudes_and_intentions_among_Indonesian_business_students/in ks/0deec52flad3aadfa2000000.pdf. Retrieved on July 01, 2020. 